\title{
Evaluation of Midwifery and Nursing Practices for Maternal and Neonatal Safety in the Delivery Room
}

\section{Doğumhanede Anne ve Yenidoğan Güvenliğinin Sağlanmasında Ebe ve Hemşirelik Uygulamalarının Değerlendirilmesi}

\author{
(D) Gamze ACAVUT¹, (D) Gülşen VURAL², id Kazım Emre KARAŞAHIN³
}

1Ankara Medipol University, Faculty of Health Science, Department of Nursing, Ankara, Turkey

${ }^{2}$ Near East University Faculty of Health Sciences, Department of Nursing, Nicosia, KKTC

${ }_{3}^{3}$ Gülhane Training and Research Hospital, Department of Obstetrics and Gynecology, Ankara, Turkey

\begin{abstract}
Objective: Delivery rooms are places where problems rapidly develop and decisions are quickly taken. Therefore, patient safety practices are among the most important things. This study was conducted to discover patient safety practices of nurses and midwives who work in the delivery room.
\end{abstract}

Methods: This descriptive study was conducted with 140 midwives and nurses working in eight hospitals in Ankara. Data were collected with a questionnaire, which was developed by reviewing the literature. Research data were analyzed by number and percentile distribution.

Results: No controlled doors were found in $1 / 3$ of the eight delivery rooms in hospitals, $21.1 \%$ of participants did not attach identity wristband while taking mothers to delivery rooms, $34.3 \%$ used room/bed numbers in detecting identity, and $63 \%$ did not register the given instructions during the emergency-sterile applications. Additionally, 8.6\% left mothers and babies alone, $27.9 \%$ did not write the date of the birth on the identity wristband, $11.4 \%$ did not follow uterus involution.

Conclusion: Our study results revealed that most targets for ensuring maternal and neonatal safety are achieved in delivery rooms. However, deficiencies were found in the application, such as identity control, applications registration, and drug administration. The majority of patient safety applications are routine practices of nurses and midwives. Training for midwives and nurses who work in delivery rooms for the safety of mother-newborn is recommended.

\section{ÖZ}

Amaç: Doğumhaneler problemlerin hızlı geliştiği ve kararların hızlı alındığı yerlerdendir. Bu nedenle hasta güvenliği uygulamaları en önemli konular arasındadır. Bu araştırma, doğumhanede çalışan ebe ve hemşirelerin hasta güvenliği uygulamalarını araştırmak amacıyla yapılmıştır.

Yöntemler: Tanımlayıcı nitelikteki bu çalışma, Ankara'da sekiz hastanede çalışan 140 ebe/hemşire ile yürütülmüştür. Araştırma verileri, literatür doğrultusunda oluşturulan bir anket aracilığıyla, yüz yüze görüşülerek toplanmıştır. Veriler sayı ve yüzde ile analiz edilmiştir.

Bulgular: Doğumhanelerin 1/3'ünde "kontrollü kapı" olmadığı, ebe ve hemşirelerin $\% 21,1$ 'inin anneyi servise kabul ederken kimlik bilekliği takmadığı, \%34,3’ünün kimlik doğrularken oda/ yatak numarası kullandığı, \%63'ünün acil-steril uygulamalar sırasında verilen talimatları kayıt altına almadığı belirlenmiştir. Ebe ve hemşirelerin \%8,6'sının anne ve bebeği doğumhanede yalnız bıraktığı, \%27,9'unun bebeğin doğum tarihini kimlik bilekliği üzerine yazmadığını, \%11,4’ünün uterus involüsyonunu takip etmediği bulunmuştur.

Sonuç: Araştırma sonuçlarına göre doğum salonlarında anne ve bebek güvenliğinin sağlanmasına yönelik hedeflerin çoğunun gerçekleştirildiği belirlenmiştir. Ancak uygulamada kimlik doğrulama, kayıt tutma, ilaç uygulama gibi konularda eksiklerin olduğu belirlenmiştir. Doğum salonlarında görev yapan ebe ve

Address for Correspondence: Gamze ACAVUT, Ankara Medipol University, Faculty of Health Science,

Cite this article as: Acavut G, Vural G, Karaşahin KE. Evaluation of Midwifery and Nursing Practices for Maternal and Neonatal Safety in the Delivery Room. Bezmialem Science 2022;10(1):73-80 


\section{Introduction}

The World Health Organization (WHO) defines patient safety as the minimization of the risk of harm in health care (1). Patient safety aims to decrease errors during the presentation to health care services and protect patients from harm due to medical error (2).

By developing medical technologies, many improvements are made within health services; however, medical errors and associated deaths continue to be frequently observed (3). A medical error is a preventable adverse effect of medical care, whether or not it is evident or harmful to the patient (4). The medical errors that commonly occur during health care providers include adverse drug events and improper transfusions, misdiagnosis, under and overtreatment, surgical injuries, wrong-site surgery, falls, infections, suicides, and mistaken patient identities (5). A medical error was determined to rank fourth among the reasons for death after cardiac disease, cancer, and chronic lower respiratory diseases (6). According to estimations of the WHO, 1 out of every 10 people is harmed while receiving health care in developed countries (7). Further, 10 out of every 100 people who are hospitalized in developing countries are exposed to infection while in the hospital, and the risk of exposure to infection could have been reduced using low-cost measures in half of this cases (7). According to reports of the Institute of Medicine, between 44,000 and 98,000 people in the USA lose their lives annually due to medical errors. These reports state that cases cost 17-20 billion dollars each year (8).

Medical errors that threaten patient safety can be frequently seen in many countries. A study that analyzed 60,599 discharged patients who experienced an event that threaten their safety revealed that $4 \%$ were exposed to an undesirable experience (falls, medication events, equipment events, etc.) (9). Annually, 24,500 people are estimated to die in Iran due to medical errors. Additionally, more adverse events are experienced in subjects, such as drug preparation, prescribing, and transcribing (10). A study in Canada revealed highly preventable adverse events in $36.9 \%$ of patients with adverse events, wherein $9 \%$ of these adverse events can be prevented (11). A study carried out in Portugal found that medical errors prolong hospitalization by 10.7 days (12). As a result of common problems, such as death, infection, and financial loss occurring due to medical error, the term patient safety has emerged (13).

Delivery rooms are places where health risks momentarily emerge and quick decisions are necessary; therefore, the risks associated with patient safety are high (14). Throughout the process, from awareness of pregnancy to the delivery room right through until postnatal services, many problems are possible, such as drug administration, identification errors, and patient falls. Patient safety problems are common in delivery rooms, especially when more than one birth takes place at a time (15).

The Canadian Medical Protective Association stated that in 20102014, 688 obstetric medical-legal cases took place, and of these cases, 395 pertained to newborn care. Additionally, 6\% of gynecologists in Canada are called to the court regarding their practices annually (16). Maternal mortality rates decrease in the global world; however, these rates are still high. In Sub-Saharan Africa, 56\% of the 287,000 maternal deaths worldwide that occurred in 2010 in this area were due to obstetric complications $(15,17)$.

According to the 2018 data of the Turkish Demographic and Health Research department, $2.2 \%$ of baby deaths are neonatal deaths (18). These results emphasize the importance of care given in the newborn period. The WHO reports that $22-45 \%$ of all neonatal deaths occur within the first $24 \mathrm{~h}$. Moreover, $80 \%$ of neonatal deaths are due to infection and birth trauma (19).

The National patient safety targets are helpful in the provision of secure health care. These targets involve correct procedures for patient identification, effective communication, drug safety enabling, and correct allocation of the surgery site, decreasing infection risks in health services, and preventing patient harm due to falls (20).

Specific measures should be taken, as well as research in patient safety in delivery rooms. The importance of patient safety is emphasized in many studies; however, literature on patient safety in the delivery room (identity control, infection prevention, drug safety, fall reduction, and first care of the mother and the baby) is restricted. Therefore, evaluating the practices of midwives and nurses regarding patient safety is important. Additionally, our research elucidates the status of applications, such as identity control, drug administration, fall prevention, and provision of mother-baby care for patient safety in the delivery room. Thus, this study will narrow the knowledge gap in the labor and delivery room about patient safety. This study aimed to determine maternal and neonatal safety in the delivery room. Identity control, drug administration, fall prevention, and first care of mother-baby in delivery rooms were determined. In line with these issues, the midwife, and nursing practices were assessed.

This descriptive study was conducted to determine the practices of midwives and nurses in delivery rooms, which is based on the Joint Commission International (JCI) patient safety criteria and affects the safety of mother and newborn.

\section{Methods}

\section{Study Design and Participants}

This study was descriptively conducted to determine the practices of midwives and nurses who work in eight hospital delivery 
rooms on how they maintain the safety of mothers and their babies. This study evaluated the nursing and midwifery practices within the scope of JCI's patient safety criteria.

All non-accredited state hospitals and university hospitals in a city center were included in the study. The universe of the study was composed of 179 midwives and nurses working in eight hospital delivery rooms. Including all midwives and nurses who work in the delivery rooms of all non-accredited state and university hospitals was planned. All nurses and midwives were aimed to be accessed but only 140 midwives and nurses (approximately $80 \%$ of the population) agreed to participate. This study excluded 39 midwives and nurses due to their refusal to voluntarily join and they were off work. After the data collection, a power analysis was done with the $G^{*}$ power program, which revealed sufficient research power (power $=0.81$ ) and sample size.

\section{Participant Inclusion Criteria}

All midwives and nurses who volunteered to participate in the study that speak Turkish and work in the delivery room were included in the study.

\section{Participant Exclusion Criteria}

Those who refuse to voluntarily join, on leave, and work in obstetrics and gynecology services are not excluded from the study.

\section{Data Collection}

Data were collected with face-to-face interviews that were conducted by the researchers using a questionnaire that was prepared through a literature review $(4,7,8)$. The questionnaire was evaluated by four academic nurses who specialize in gynecology and obstetrics. Necessary changes were made to the questionnaire following the suggestions of these experts. The questionnaire included two sections. The first section has five questions asking about the characteristics of delivery rooms; whereas the second section has seven questions asking about the socio-demographic characteristics of the participants and 56 questions (fewer than seven headings) related to patient safety targets. These questions were about identification checking, communication, drug safety, infection, preventing falls, and initial care of newborns and mothers.

\section{Ethical Considerations}

The study protocol was approved by the Turkish Republic Ministry of Health and the Gülhane Military Medical Academy Ethical Committee (no: 169) and Local Ethics Committee (no: 25.02.2011/46136). The study was conducted following the Declaration of Helsinki. The objectives of the study were explained to the participants to comply with ethical considerations. All the participants signed the written informed consent before enrolment. The participants were free to withdraw from the study at any time and stage. All responses were stored safely.

\section{Statistical Analysis}

The Statistical Package for Social Sciences ver.15 software was used for statistical analysis. Numbers were shown as percentage, mean, and standard deviation to identify the characteristics of nurses and midwives, as well as descriptive statistics.

\section{Results}

Of the midwives and nurses who participated in the study, $55.7 \%$ were 33 years old or younger and $51.4 \%$ had are both undergraduate and postgraduate. Nurses constituted $42.9 \%$ of the total number of participants, whereas midwives made up the remaining $53.5 \%$. Of the midwives and nurses, 55\% had 10 years of occupational experience, $49.3 \%$ had served in a delivery room for $>3$ years, and $73.6 \%$ worked for $40 \mathrm{~h}$ a week (Table 1 ).

The analyses of safety practices of the midwives and nurses related to identity checking revealed that $97.1 \%$ checks the identity when taking the pregnant women to the delivery room and $72.8 \%$ checked the protocol number. Of the participants, $78.8 \%$ attached the patient identity wristband when taking the patients to the delivery room. When checking identity, 96.4\% of the midwives and nurses used to name and surname together, whereas $34.3 \%$ used room or bed number and $99.3 \%$ checked the identity before any practices (Table 2 ).

Of the midwives and nurses, $65 \%$ did not receive verbal or telephone instructions from doctors apart from during sterile emergency practices. While taking verbal or telephone instructions

Table 1. Distribution of midwives/nurses by their sociodemographic characteristics

\begin{tabular}{|c|c|c|}
\hline Socio-demographic characteristics & Number & $\%$ \\
\hline \multicolumn{3}{|l|}{ Age group } \\
\hline 33 years and under & 78 & 55.7 \\
\hline 34-37 years & 34 & 24.3 \\
\hline 38 years or above & 28 & 20.0 \\
\hline \multicolumn{3}{|l|}{ Education level } \\
\hline Vocational school of health & 19 & 13.6 \\
\hline Associate degree & 49 & 35.0 \\
\hline Undergraduate and graduate & 72 & 51.4 \\
\hline \multicolumn{3}{|l|}{ Occupation } \\
\hline Chief-nurse & 5 & 3.6 \\
\hline Nurse & 60 & 42.9 \\
\hline Midwives & 75 & 53.5 \\
\hline \multicolumn{3}{|l|}{ Occupations working time } \\
\hline Less than 1 year & 8 & 5.7 \\
\hline $1-5$ years & 39 & 27.9 \\
\hline $5-10$ years & 16 & 11.4 \\
\hline More than 10 years & 77 & 55.0 \\
\hline \multicolumn{3}{|c|}{ Occupational time in the delivery room } \\
\hline Less than 3 year & 71 & 50.7 \\
\hline 3-6 years & 42 & 30.0 \\
\hline More than 6 years & 27 & 19.3 \\
\hline \multicolumn{3}{|l|}{ Working hours in a week } \\
\hline 40 hours & 103 & 73.6 \\
\hline 45 hours & 29 & 20.7 \\
\hline 48 hours or above & 8 & 5.7 \\
\hline
\end{tabular}


from a doctor for sterile emergency practices, $65.4 \%$ of midwives and nurses stated that they write down the instructions, $46.3 \%$ read the instructions back to the doctor, and $81.6 \%$ ask for the instructions to be confirmed by the instructor. While only $37 \%$ of midwives and nurses record instructions for sterile emergency practices, $99.3 \%$ stated they convey information about patients to the team on night duty during shift changeovers (Table 3).

The analyses of the drug safety practices of midwives and nurses revealed that $98.6 \%$ classify drugs according to their names and all store drugs according to a cold chain. Of the midwives and nurses, $86.4 \%$ recorded the opening time (date) of the drug, whereas $68.6 \%$ record the opening hour of the drug (Table 4).

Of the midwives and nurses, $97.8 \%$ obtain data from pregnant women about drugs that they have been using. Moreover, all participants ask the pregnant woman about drug allergies when taking them to the delivery room and adopt eight correct principles of drug practices (Table 4).

Considering the distribution of safety practices to decrease infection risks, $99.3 \%$ of midwives and nurses wash their hands before and after practices. Moreover, 58.6\% make other staff wash their hands, and $97.1 \%$ control maternal blood results for infectious disease. All midwives and nurses apply aseptic techniques during practices and check sterilization dates before they use sterile materials. Additionally, all midwives and nurses open the materials they use without breaking the sterilization and send the materials they used to be sterilized under suitable conditions. Of the midwives and nurses, $8.6 \%$ do not give perineum care to mothers in the delivery room (Table 5).

\begin{tabular}{l|l|l|}
\multicolumn{2}{|c|}{ Table 2. Checking identity applications of midwives and } \\
nurses
\end{tabular}

All participants said they make the length of the obstetric/ birth table suitable for the mother to prevent falls. Moreover, all participants use stretchers or wheelchairs to transfer mothers during postpartum and accompany them while they are being transferred to prevent falls. Of the participants, $91.4 \%$ do not leave mothers and babies alone in the delivery room. Likewise, $41.4 \%$ of midwives and nurses do not use an incubator while transporting a baby (Table 6).

Considering the initial newborn care practices of midwives and nurses in patient safety, $95.7 \%$ securely hold the baby (supporting the baby by holding the head and body, monitoring whether the cord goes around the neck of the baby, and keeping the babies level with the vagina) and $98.6 \%$ leave the baby in radiant heat as soon as possible after delivery. All participants use a sterile catheter while aspirating the baby.

Of the participants, $85.7 \%$ confirm the gender of the baby with its mother and attach wristband to the baby and mother in the same color and code. Nearly all (98.6\%) midwives and nurses write the name and surname of the mother and $72.1 \%$ write the baby's date of birth on the identity wristband. Most (97.9\%) midwives and nurses evaluate the umbilicus regarding bleeding and enable the first contact between mother and baby. Of the participants, $96.4 \%$ enable the baby to be breastfed within half an hour after birth and all participants record all their practices.

The analysis of midwives' and nurses' initial care practices for mothers revealed that they monitor the vital signs of mothers

Table 3. Taking order (instructions) verbal/telephone applications of midwives and nurses

\begin{tabular}{|c|c|c|}
\hline Applications of midwives and nurses & Number & $\%$ \\
\hline \multicolumn{3}{|l|}{$\begin{array}{l}\text { Taking orders by verbal/telephone except } \\
\text { for emergency-sterile applications }\end{array}$} \\
\hline Yes & 49 & 35.0 \\
\hline No & 91 & 65.0 \\
\hline \multicolumn{3}{|l|}{ Emergency-sterile applications } \\
\hline \multicolumn{3}{|l|}{ Write the order } \\
\hline Yes & 89 & 65.4 \\
\hline No & 47 & 34.6 \\
\hline \multicolumn{3}{|l|}{ Repeat order } \\
\hline Yes & 63 & 46.3 \\
\hline No & 73 & 53.7 \\
\hline \multicolumn{3}{|l|}{ Confirm the order } \\
\hline Yes & 111 & 81.6 \\
\hline No & 25 & 18.4 \\
\hline \multicolumn{3}{|l|}{$\begin{array}{l}\text { Recording the order in emergency-sterile } \\
\text { applications }(n=138)\end{array}$} \\
\hline Yes & 51 & 37.0 \\
\hline No & 87 & 63.0 \\
\hline \multicolumn{3}{|l|}{$\begin{array}{l}\text { Convey all patient information during shift } \\
\text { changeovers }\end{array}$} \\
\hline Yes & 139 & 99.3 \\
\hline No & 1 & 0.7 \\
\hline
\end{tabular}


and evaluate their pain and fatigue status. Additionally, 99.3\% give information to the mother about interventions. Of the total midwives and nurses, $92.9 \%$ monitor bleeding, $88.6 \%$ monitor uterus involution, and $98.6 \%$ meet the hygiene needs of mothers.

As a limitation of our research, the answers to the questions within the scope of the questionnaire were only obtained by the participants' declaration. Conducting observational research, which would strengthen the research results, was impossible.

\section{Discussion}

The practices of midwives and nurses are critically important in delivery rooms; however, a review of the existing literature found no studies about maternal and neonatal safety in delivery rooms.

A literature review done with hospital nurses revealed that the use of surnames to check the identity was similar to our results (21). A literature review revealed that nearly half of the staff used surnames to check their identity (22). Our study revealed that one out of three participants uses room or bed numbers to identify patients, which is a known cause of faulty medical practices. Patient identification is an area of high priority in delivery rooms, with an error, or adverse event regarding noncompliance in patient identification. General conformity rates

Table 4. Drug safety applications of midwives and nurses

\begin{tabular}{|c|c|c|}
\hline Applications of midwives and nurses & Number & $\%$ \\
\hline \multicolumn{3}{|l|}{ Classify drugs according to their names } \\
\hline Yes & 138 & 98.6 \\
\hline No & 2 & 1.4 \\
\hline \multicolumn{3}{|l|}{ Storage in a cold chain } \\
\hline Yes & 140 & 100.0 \\
\hline No & - & - \\
\hline \multicolumn{3}{|l|}{ Record the following: } \\
\hline \multicolumn{3}{|l|}{ Name of drug } \\
\hline Yes & 134 & 95.7 \\
\hline No & 6 & 4.3 \\
\hline \multicolumn{3}{|l|}{ Opening date of the drug } \\
\hline Yes & 121 & 86.4 \\
\hline No & 19 & 13.6 \\
\hline \multicolumn{3}{|l|}{ The opening hour of the drug } \\
\hline Yes & 96 & 68.6 \\
\hline No & 44 & 31.4 \\
\hline \multicolumn{3}{|l|}{ Asking for the: } \\
\hline Drugs used by the pregnant women & 136 & 97.8 \\
\hline No & 3 & 2.2 \\
\hline Drug allergy & 140 & 100.0 \\
\hline Yes & - & \\
\hline No & & 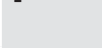 \\
\hline $\begin{array}{l}\text { Eight correct principles of drug practices } \\
\text { Yes }\end{array}$ & 140 & 100.0 \\
\hline No & - & - \\
\hline
\end{tabular}

between mother and baby is another problem in delivery rooms. Bates et al. (23) revealed in their study considerably lower general conformity rates, especially in identifying newborns at the delivery room. The study results by Filiz (24) revealed a high rate for using room or bed numbers to identify patients. A literature review with health staff working at hospitals and cottage hospitals is also parallel with our results $(23,24)$. Our study revealed that nearly one-quarter of midwives and nurses do not attach identity wristbands to pregnant women when taking them to the delivery room. Matching the right patient with the right care is an important issue of safe health care. Patient wristbands form a vital link between the patient and the health care system. However, our study revealed that identity wristbands are not generally attached to pregnant women before taking them to the delivery room. This increases the risk of errors in the delivery room.

The study of Henneman et al. (25) in emergency services nurses revealed parallel results with our study. Moreover, in both studies conducted on health personnel, the number of those who do not use identity wristbands was higher than in our results $(24,26)$. Some studies revealed that the rate of errors in the use of identity wristbands was high $(25,27)$. Therefore, the use of identity wristbands instead of room/bed numbers is important to ensure maternal and neonatal safety in the delivery room.

The study of Mrayyan et al. (28) revealed that wrong labeling or classification of drugs is the primary reason for drug error as stated by nurses. Our study revealed that nearly all participants classify drugs according to their names and all maintain drugs according to the cold chain. Fisun et al. (29) revealed are parallel results to

\section{Table 5. Applications of midwives and nurses to prevent infection}

\begin{tabular}{l|l|l}
\hline $\begin{array}{l}\text { Applications of midwives and nurses } \\
\text { Wash hands before and after practices }\end{array}$ & 139 & 99.3 \\
$\begin{array}{l}\text { Yes } \\
\text { No }\end{array}$ & 1 & 0.7 \\
\hline $\begin{array}{l}\text { Control hand washing of other staff } \\
\text { Yes }\end{array}$ & 82 & 58.6 \\
\hline $\begin{array}{l}\text { No } \\
\text { Control maternal blood results for } \\
\text { infectious disease }\end{array}$ & 58 & 41.4 \\
\hline $\begin{array}{l}\text { Yes } \\
\text { No }\end{array}$ & 136 & 97.1 \\
\hline $\begin{array}{l}\text { Applying aseptic techniques } \\
\text { Yes }\end{array}$ & 4 & 2.9 \\
\hline $\begin{array}{l}\text { No } \\
\text { Checking sterilization dates }\end{array}$ & 140 & 100.0 \\
\hline $\begin{array}{l}\text { Yes } \\
\text { No }\end{array}$ & - & - \\
\hline $\begin{array}{l}\text { Giving perineum care to mothers } \\
\text { Yes }\end{array}$ & 140 & 100.0 \\
\hline No & - & - \\
\hline & 128 & 91.4 \\
\hline & 12 & 8.6 \\
\hline
\end{tabular}


our study. Our study revealed that nearly all participants write the drug name on the injector, but one-third said they do not write the date and time the drug seal was opened. An observational study about the drug practices of nurses revealed that none of the nurses drew the drug left in the vial and all keep it at room temperature. Moreover, $44.7 \%$ of the drugs had no opening date or time, and $55.3 \%$ of the labeled ones contained imperfect information (30). Our study revealed that all participants asked about drug allergies while taking the patients to the delivery room and apply eight correct drug practice principles. The literature review supports these results $(29,30)$. Therefore, we can say that as a routine practice of nursing, nurses classify drugs according to names and dates. However, they did not write the date and time the drug seal was opened.

Nearly all participants in our study pay attention to washing hands and sterilization_to decrease infection risks in the delivery room. Other studies revealed that health staffs pay attention to hand hygiene and adapt to asepsis rules $(31,32)$. Additionally, the literature emphasized the importance of hand washing and hygiene, and midwives and nurses should be careful with effective management of coronavirus disease-2019 (COVID-19) in the delivery room $(33,34)$.

Risks have been identified through a scale developed in 2010 to prevent falls for newborns (35). Nearly all participants adjusted the delivery table to a suitable height and transferred mothers to prenatal areas using a stretcher or wheelchair. However, nearly half of the participants did not use an incubator while transporting a baby. Another study showed that the use of incubators for this purpose was also quite low (36). Moreover, our study revealed that some participants left mothers and babies alone in the delivery room. These results provide information

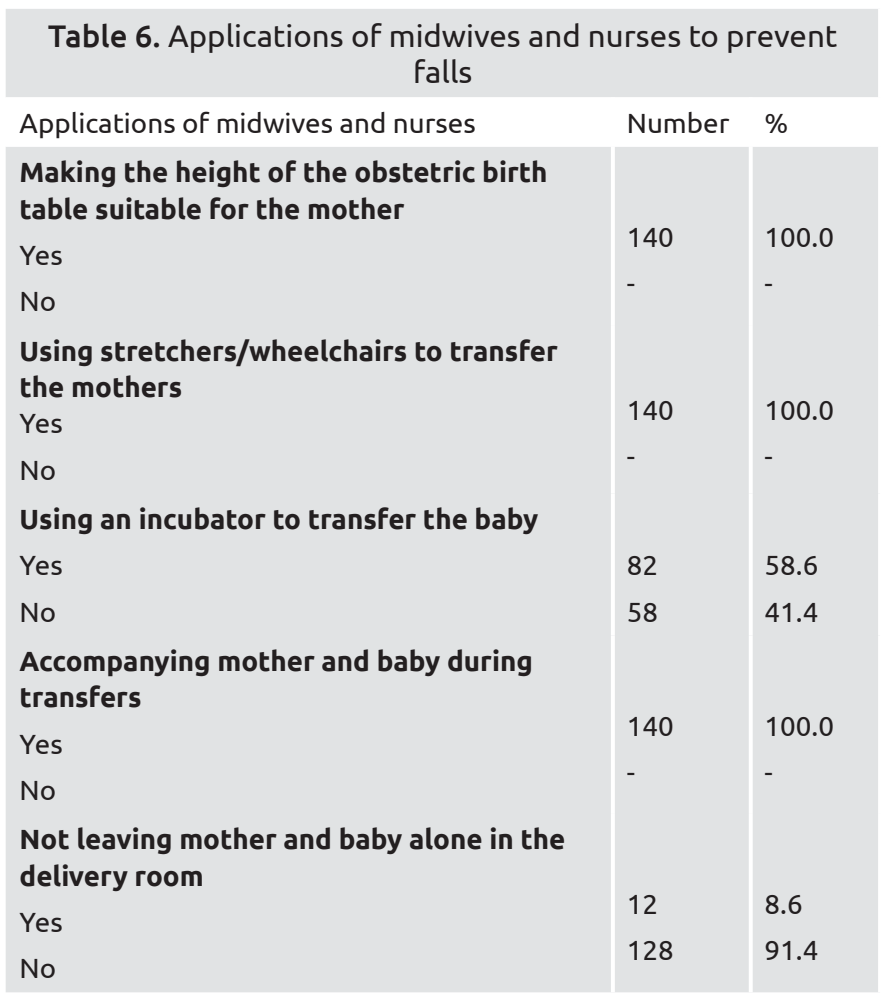

Table 7. Newborn and mother care practices

\begin{tabular}{|c|c|c|}
\hline Applications of midwives and nurses & Number & $\%$ \\
\hline \multicolumn{3}{|l|}{ Hold the baby in a secure way } \\
\hline Yes & 134 & 95.7 \\
\hline No & 6 & 4.3 \\
\hline \multicolumn{3}{|l|}{ Leaving the baby in radiant heat } \\
\hline Yes & 138 & 98.6 \\
\hline No & 2 & 1.4 \\
\hline \multicolumn{3}{|l|}{$\begin{array}{l}\text { Using sterile catheter while aspirating the } \\
\text { baby }\end{array}$} \\
\hline Yes & 140 & 100.0 \\
\hline No & - & - \\
\hline \multicolumn{3}{|l|}{ For baby } \\
\hline \multicolumn{3}{|l|}{ Confirm the gender } \\
\hline Yes & 120 & 85.7 \\
\hline No & 20 & 14.3 \\
\hline \multicolumn{3}{|l|}{ Attach wristband same color and code } \\
\hline Yes & 139 & 99.3 \\
\hline No & 1 & 0.7 \\
\hline \multicolumn{3}{|l|}{$\begin{array}{l}\text { Write the mother's name-surname on the } \\
\text { wristband }\end{array}$} \\
\hline Yes & 138 & 98.6 \\
\hline No & 2 & 1.4 \\
\hline \multicolumn{3}{|l|}{ Write baby's birth date on the wristband } \\
\hline Yes & 101 & 72.1 \\
\hline No & 39 & 27.9 \\
\hline \multicolumn{3}{|l|}{ Evaluate the umbilicus for bleeding } \\
\hline Yes & 137 & 97.9 \\
\hline No & 3 & 2.1 \\
\hline \multicolumn{3}{|l|}{ Breastfed within half an hour } \\
\hline Yes & 135 & 96.4 \\
\hline No & 5 & 3.6 \\
\hline \multicolumn{3}{|l|}{$\begin{array}{l}\text { Monitor mother's vital signs, pain, and } \\
\text { fatigue }\end{array}$} \\
\hline Yes & 140 & 100.0 \\
\hline No & - & - \\
\hline \multicolumn{3}{|l|}{$\begin{array}{l}\text { Provide information to the mother about } \\
\text { interventions }\end{array}$} \\
\hline Yes & 139 & 99.3 \\
\hline No & 1 & 0.7 \\
\hline \multicolumn{3}{|l|}{ For mother } \\
\hline \multicolumn{3}{|l|}{ Monitoring bleeding } \\
\hline Yes & 130 & 92.9 \\
\hline No & 10 & 7.1 \\
\hline \multicolumn{3}{|l|}{ Monitoring uterus involution } \\
\hline Yes & 124 & 88.6 \\
\hline No & 16 & 11.4 \\
\hline \multicolumn{3}{|l|}{ Ensuring hygiene } \\
\hline Yes & 138 & 98.6 \\
\hline No & 2 & 1.4 \\
\hline
\end{tabular}


on the development of midwifery and nursing practices in the prevention of patient falls and life-threatening conditions.

In the United States, 600-1,600 newborns experience hospital falls annually (37). Manson et al. (38) reported that 14 baby fall cases occurred in 888,774 births, of which four happened in the delivery room, thus the importance of the issue was emphasized. Trauma incidents of the newborn that result from falling were found to be 1.6 per 10,000 (38). Our study revealed that nearly all participants paid attention to securely holding the babies to prevent trauma. The majority of midwives and nurses attach color and number-coded identity wristbands for both the mother and baby to prevent mistaking the identity of the baby, as well as writing the name and surname of the mother. However, nearly one-quarter of midwives and nurses did not write the birth date of the baby. The majority of patient safety applications were routinely practiced by nurses and midwives.

All participants monitor the vital signs of mothers before and after birth and evaluate their fatigue status. A study carried out by Lai et al. (39) showed that high levels of fatigue caused difficulties for baby care and falling, and emphasized the importance of attentively evaluating the fatigue of mothers. Our study revealed that nearly all participants evaluate the bleeding of mothers and assist them with body hygiene. Additionally, the majority of midwives and nurses evaluated uterus involution. Another study revealed an $80 \%$ rate of midwives and nurses who controlled bleeding in the postnatal period (40). Controlling the bleeding after birth and assisting body hygiene are very important measures to prevent infection and provide patient safety.

\section{Study Limitations}

One limitation of our study could be considered as giving the questionnaires to nurses and midwives who may be scared to reveal an improper behavior concerning patient safety due to possible medicolegal consequences. However, as we have assured them the anonymity of the data, we believe that every participant honestly answered the questionnaire. No scale has been developed or used in data collection. Therefore, make validity and reliability is not necessary.

\section{Conclusion}

Our study results highlight the deficiencies in maternal and neonatal safety in delivery rooms. Thus, the applications of midwives and nurses including covers identity control, prevention of infections, drug safety, reduction of falls, and the first care of the mother and the baby are suggested to be examined with more comprehensive research along with their results. Additionally, taking measures to prevent COVID-19 infection in the delivery room is also recommended, as well as train nurses and midwives on the subject.

Delivery rooms are places where health risks momentarily emerge and quick decisions are necessary; therefore, the risks associated with patient safety are high. Additionally, more descriptive research/observational studies are needed in this area.

\section{Ethic}

Ethics Committee Approval: Turkish Republic Ministry of Health and the Gülhane Military Medical Academy Ethical Committee (no: 169) and Local Ethics Committee (no: 25.02.2011/46136).

Peer-review: Externally peer reviewed.

\section{Authorship Contributions}

Concept: G.A., G.V., Design: G.A., G.V., Data Collection or Processing: G.A., Analysis or Interpretation: G.A., G.V., K.E.K., Literature Search: G.A., G.V., K.E.K., Writing: G.A., G.V., K.E.K.

Conflict of Interest: No conflict of interest was declared by the authors.

Financial Disclosure: The authors declared that this study received no financial support.

\section{References}

1. WHO, Patient Safety. Definitions of Key Concepts from the WHO Patient Safety Curriculum Guide, 2011. http://www.who. int/patientsafety/education/curriculum/course1a_handout.pdf. Accessed: December 15, 2018.

2. Leape LL. Patient Safety in the Era of Healthcare Reform. Clin Orthop Relat Res 2015; 473:1568-73.

3. Hashjin AA, Kringos DS, Manoochehri J, Ravaghi H, Klazinga NS. Implementation of Patient Safety and Patient-Centeredness Strategies in Iranian Hospitals. PLoS One 2014;9:e108831.

4. Hofer TP, Kerr EA, Hayward RA. What is an error? Eff Clin Pract 2000;3:261-9.

5. Carver N, Gupta V, Hipskind JE. Medical Error. Stat Pearls [Internet]. Treasure Island (FL): Stat Pearls Publishing; 2020;Feb 16.

6. National Center for Health Statistics (US). Health, United States: With Special Feature on Adults Aged 55-64. Hyattsville (MD): National Center for Health Statistics (US); 2015; Report No.: 2015-1232.

7. WHO, 10 Facts on Patient Safety, 2014. https://www.who.int/ features/factfiles/patient_safety/en/. Accessed: December 10, 2018.

8. Institute of Medicine (US) Committee on Quality of Health Care in America. To Err is Human: Building a Safer Health System. Kohn LT, Corrigan JM, Donaldson MS, editors. Washington (DC): National Academies Press (US); 2000. PMID: 25077248.

9. Naessens JM, Campbell CR, Huddleston JM, Berg BP, Lefante JJ, Williams AR, et al. A Comparison of Hospital Adverse Events Identified by Three Widely Used Detection Methods. Int J Qual Health Care 2009;21:301-7.

10. Zargarzadeh A. Medication Safety in Iran. J Pharm Care 2013;1:1256.

11. Baker GR, Norton PG, Flintoft V, Blais R, Brown A, Cox J, et al. The Canadian Adverse Events Study: the incidence of adverse events among hospital patients in Canada. CMAJ 2004;170:1678-86.

12. Sousa P, Uva, AS, Serranheira F, Nunes C, Leite ES. Estimating the Incidence of Adverse Events in Portuguese Hospitals: A Contribution 
to Improving Quality and Patient Safety. BMC Health Serv Res 2014;14:311.

13. Wilson RM, Michel P, Olsen S, Gibberd RW, Vincent C, ElAssady R, et al. Patientsafety in developing countries: retrospective estimation of scale and nature of harm to patients in hospital. BMJ 2012;344:e832.

14. Vural G. Maternity and Women's Health Nursing (Book) (2011). (Ed: Taşkın L.) Ankara: Sistem Ofset. ISBN:975-94661-0-4.

15. Kruk ME, Hermosilla S, Larson E, Mbaruku GM. By passing primary care clinics for childbirth: a cross-sectional study in the Pwani region, United Republic of Tanzania. Bull World Health Organ 2014;92:246-53.

16. Canadian Medical Protective Association (CMPA). Obstetrics Services in Canada Advancing Quality and Strengthening Safety, 2016.

17. Trends in maternal mortality: 1990 to 2010: WHO, UNICEF and The World Bank estimates WHO; 2012. http://apps.who.int/iris/ bitstream/10665/44874/1/9789241503631_eng.pdf. Accessed: December 10,2018

18. Turkey Demographic and Health Survey, 2018. Hacettepe University Institute of Population Studies, Ankara, Turkey. http://www.hips. hacettepe.edu.tr/tnsa2018/rapor/TNSA2018_ana_Rapor.pdf Accessed: June10, 2020.

19. WHO, Newborns: reducing mortality. Factsheet. 2012. https://www. who.int/news-room/fact-sheets/detail/newborns-reducing-mortality. Accessed: December 10,2018.

20. JCAHO, Hospital National Patient Safety Goals. 2015. http:// www.jointcommission.org/assets/1/6/2015_HAP_NPSG_ER.pdf. Accessed: December 15,2018.

21. Gökdoğan F, Yorgun S. Patient Safety and Nurses in Health Services. Journal of Anatolia Nursing and Health Sciences 2010;13:2, 53-9.

22. McCoy AB, Wright A, Kahn MG, Shapiro JS, Bernstam EV, Sittig DF. Matching Identifiers in Electronic Health Records: Implications for Duplicate Records and Patient Safety. BMJ Qualand Saf 2013;22:219-24.

23. Bates DW, Larizgoitia I, Prasopa-Plaizier N, Jha AK, Research Priority Setting Working Group of the WHO World Alliance for Patient Safety. Global priorities for patient safety research. BMJ 2009;14;338:b1775.

24. Filiz E. Determination of perception of patient safety culture in hospitals and of health staff and patient attitudes about patient safety. Selçuk University, Institute of Health Sciences, 2009. Department of Public Health. Master Thesis. Konya, Turkey.

25. Henneman PL, Fisher DL, Henneman EA, Pham TA, Campbell MM, Nathanson BH. Patient Identification Errors are Common in a Simulated Setting. Ann Emerg Med 2010;6: 503-9.

26. Ögün B. The Study of Patient Safety in the Operating Room. Hacettepe University, Institute of Health Sciences, 2008. Surgical Nursing Department. Master Thesis. İstanbul, Turkey.
27. Hain PD, Joers B, Slayton J, Throop P, Hoagg S, Allen L, et al. An Intervention to Decrease Patient Identification Band Errors in a Children's Hospital. Qualand Saf Health Care 2010;19:244-7.

28. Mrayyan MT, Shishani K, Al-Faouri I. Rate, Causes and Reporting of Medication Errors in Jordan: Nurses' perspectives. J Nursing Manag 2007;6:659-70.

29. Fisun V, Seval Ç, Birol V. Common Medication Errors and Drug Safety. Acıbadem University Journal of Health Sciences 2014;4:2715.

30. Alparslan Ö, Erdemir F, et al. Determination of Information and Practices of Nurses on Dilution, Storage and Delivery of Antibiotics Used in Pediatric Services. Journal of Cumhuriyet University School of Nursing. 1997;1(1), 41-52.

31. Cebeci F, Gürsoy E, Tekingündüz Ş. Determining the Level of Tendency in Malpractice Among Nurses. Journal of Anatolia Nursing and Health Sciences 2012;15:188-96.

32. Garus-Pakowska A, Sobala W, Szatko F. Observance of hand washing procedures performed by the medical personnel after the patient contact. Part II. Int J Occup Med Environ Health 2013;2:257-64.

33. Yeşilçınar İ, Kıncı MF. COVID-19 Pandemisinde Doğumun İntrapartum ve Postpartum Yönetimi. Ege Klinikleri Tıp Dergisi Nisan 2020;58(1),46-48.

34. World Health Organization. Coronavirus disease (COVID-19) outbreak: rights, roles and responsibilities of health workers, including key considerations for occupational safety and health. March 18, 2020. Accesed: https://www.who.int/publicationsdetail/coronavirus-disease-(covid-19)-outbreak-rights-roles-andresponsibilities-of-health-workers-including-key-considerations-foroccupational-safety-and-health

35. Abike F, Tiras S, Dünder İ, Bahtiyar A, Uzun OA, Demircan O. A New Scale for Evaluating the Risks for In-Hospital Falls of Newborn Infants: A Failure Modes and Effects Analysis Study. Int J Pediatr 2010;2010:547528.

36. Uslu S, Aldudak B, Özdemir H. The effects of improvement efforts on regional neonatal transport conditions in Diyarbakır. Turkish Archives of Pediatrics 2011;46:196-201.

37. Helsley L, McDonald JV, Stewart VT. Addressing in-hospital "falls" of newborn infants. Jt Comm J Qual Patient Saf 2010;36:327-33.

38. Manson SA, Henry E, Lambert DK, Schmutz N, Christensen RD. In-Hospital Falls of Newborn Infants: Data From a Multihospital Health Care System. Pediatrics 2008;122:e277-80.

39. Lai YL, Hung CH, Stocker J, Chan TF, Liu Y. Postpartum Fatigue, Baby-Care Activities and Maternal-Infant Attachment of Vaginal and Cesarean Births Following Rooming-in. App Nurs Res 2015;28:11620.

40. Arslan E, Vural G. Satisfaction of Mothers with Midwifery/Nursing Care Given in the Postpartum Period in Hospital. Gazi Medical Journal 2018;29:34-40. 